\title{
CONCEPTUAL SITE MODEL FOR EVALUATING CONTAMINANT MOBILITY AND PUMP-AND-TREAT REMEDIATION
}

\author{
NIKOLAOS P. NIKOLAIDIS* \\ HUIYING SHEN
}

\author{
The University of Connecticut \\ Environmental Engineering Program \\ Department of Civil and Environmental Engineering \\ 261 Glennbrook Road, FLC U-37, Storrs, CT 06269-2037 USA
}

*to whom all correspondence should be addressed

Tel: +1 (860) 486-5648

Fax: +1 (860) 486-2298

Received: 29/09/98

Accepted: 25/02/00

e-mail: nikos@engr.uconn.edu

\begin{abstract}
The development of a conceptual site model (CSM) is an invaluable tool used for assessing and planning remedial actions at a contaminated site. The CSM incorporates site-specific, hydrogeologic and geochemical information to identify contaminants of concern, sources of pollution, environmental pathways and retardation mechanisms, and points of exposure. The model is dynamic and continually revised as new information is obtained during the course of investigation. A ground water contamination case study is examined to illustrate the development and application of a CSM. The site is a metal plating facility that has contaminated the ground water with chromium. The CSM was incorporated into a 3-D fate and transport model. The Heavy Metal model, HM-3D, was used to simulate the fate and transport of chromium at the site and evaluate pump-and-treat remediation scenarios.
\end{abstract}

KEY WORDS: chromium, arsenic, column studies, metal finishing operations, municipal landfill

\section{INTRODUCTION}

Heavy metal contamination of soils and ground water associated with industrial facilities has resulted mostly from leaking of waste stream impoundments, spillage during operation, or improper disposal of hazardous waste material in non-engineered landfills. The leaching potential of heavy metals from the unsaturated zone, their mobility in groundwater and their effective remediation depend on several factors. These factors include the site's hydrogeological characteristics, solubility and speciation in the particular soil, attenuation and immobilization processes, and the extent to which the heavy metals may be dispersed both horizontally and vertically as they migrate (Nikolaidis et al., 1994). The chemical speciation of heavy metals and the factors affecting their mobility in soils, ground waters and wetlands have been extensively reviewed by Nikolaidis et al. (1994), Asikainen and Nikolaidis (1994), Lackovic et al. (1997), Mattuck and Nikolaidis (1996), Olazabal et al. (1997) and Shen and Nikolaidis (1997). 
Evaluation of contaminant mobility is a necessary component of the overall assessment of a site in order to establish either risk-based or mobilitybased, site-specific cleanup levels of remediation. Given the distributed nature of soil properties, the 3-dimensional variability of contamination and the spatial variability of the magnitude of processes that attenuate heavy metals in the subsurface, an appropriate site assessment that would lead to a successful site remediation can be extremely cumbersome. To facilitate the thought process and prioritize the actions to be taken as part of a site assessment, the environmental scientists and engineers need to develop a conceptual site model (CSM).

The conceptual site model is a planning tool designed to guide the investigation of a site through an assessment framework that integrates new site information as it becomes available. The development and revision of a CSM is the most important decision making instrument. The development can be broken down into three areas: (1) identification of all substances used or stored at the facility; (2) evaluation of potential pathways of release by characterizing the physical and chemical properties of the substances of concern; and (3) evaluation of the hydrogeology of the site to identify the most prevalent pathways of contaminant migration. Revision should incorporate all sampling information collected and all plans for handling and storage of contaminated waste products.

Typical CSMs, as described earlier, have been used extensively in the U.S. and Europe by environmental consultants in their attempt to assess a site and implement optimal remedial alternatives (Nielsen, 1991; Bear and Verruijt, 1987). In fact, certain states, such as the State of Connecticut, require the development of a CSM as part of the initial stages of site assessment and its continuous revision in the later stages of the environmental investigation. The objective of this work is to augment the framework of a CSM by including appropriate laboratory studies that assess heavy metal mobility in the subsurface and the processes that control this mobility, and illustrate the utility of a CSM by incorporating it into transport models that can simulate the behavior of contaminants in the subsurface. Figure 1 presents the development process of an augmented CSM.

\section{SITE DESCRIPTION}

National Chromium, Inc. has been in operation since 1939. During the course of normal operations, plating solutions have been allowed to percolate into the ground through a wooden-slatted floor sitting directly on top of the ground surface. In addition, chromate has been absorbed into water vapor from the chrome plating tanks and has been escaping through exhaust vents before the plant had air pollution control devices. These fugitive chromate emissions had been deposited on the roof of the facility and subsequently found their way to the ground through the gutter system. A field investigation that consisted of vertical borings and aqueous and soil chemical sampling yielded the following information. The contamination (consisting primarily of chromium, nickel, copper, zinc, cadmium, and lead) has migrated below and around the facility into the ground water, discharging to a riverine wetland $50 \mathrm{~m}$ away. Chemical characterization of the ground water identified it as mildly acidic (pH of 4 to 5.5), with oxidizing conditions (dissolved oxygen of 2 $8 \mathrm{mg} \mathrm{l}^{-1}$ ). All chromium was in the hexavalent oxidation state as chromate. The plant is located at

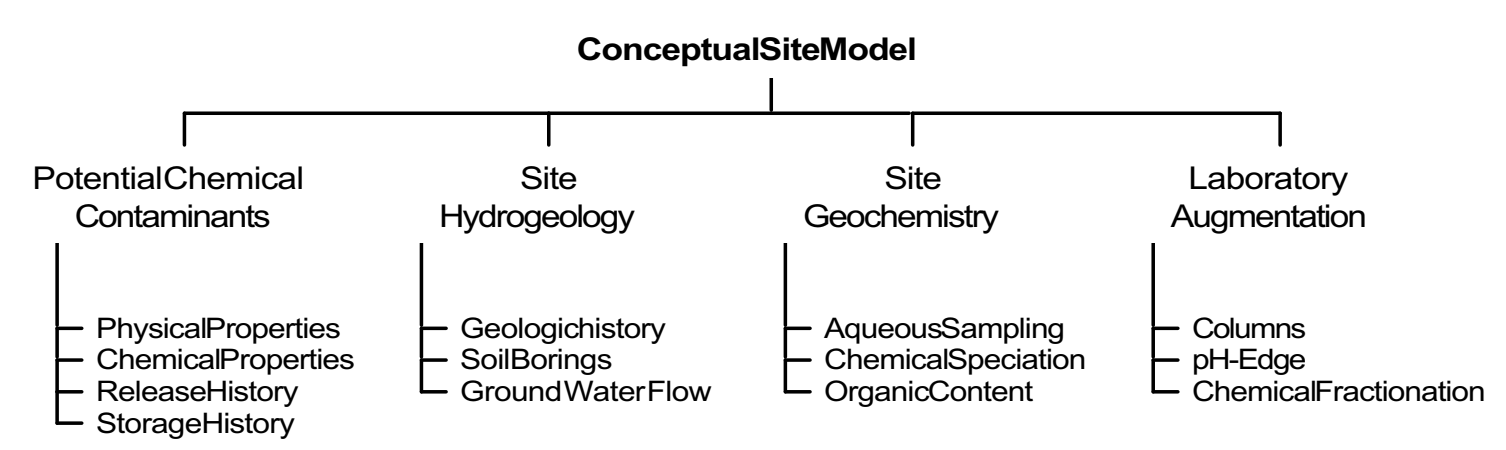

Figure 1. Development process of an augmented CSM. 
the edge of a steep kame terrace escarpment. At the base of the escarpment lie the flood plain deposits (reworked stratified drift) of the Little River. Contamination appears to be confined horizontally within a narrow valley cut into the escarpment. The contaminated zone consists of interbedded, moderately- to poorly-sorted fine sands and silt layers. The riverine deposits at the base of the escarpment are approximately 10 to $15 \mathrm{~m}$ thick (based on a seismic refraction survey). The underlying bedrock is a granitic gneiss. Based on physical probing, wetland peat sediments appear less than $0.3 \mathrm{~m}$ thick, except within the valley cut of the escarpment, where they thicken to $1.8 \mathrm{~m}$. Contamination discharges to the wetland and migrates along a discrete channel into the Little River. Between the facility and the river a heavily vegetated area, which includes a variety of trees, shrubs, and wetland perennial plants common to wetlands of the region.

\section{DEVELOPMENT OF AUGMENTED CONCEPTUAL SITE MODEL}

The CSM that resulted from the field investigation is schematically presented in Figure 2. This model can provide information regarding the sources and receptors of heavy metal contaminants (Nikolaidis et al., 1994; Asikainen and Nikolaidis, 1994) and the partitioning of the metals between the aqueous and solid phases $(99 \%$ of its mass is bound to the soil), but it can not answer questions regarding its mobility and the attenuating processes that control this mobility (Nikolaidis et al., 1994). Key questions regarding heavy metal mobility include:

1. How is chromium partitioned with the aquifer material?

2. Are the partitioning processes reversible?

3. How fast are the partitioning processes (selection of equilibrium versus kinetic model)?

4. Is there a residual level of chromium accumulation in the aquifer that produces no "observable" impact?

To answer the above questions, a series of laboratory experiments were conducted. Using the field data, an evaluation of the mechanisms retarding chromium in the ground water aquifer revealed that adsorption onto organic matter and iron oxide coatings on mineral surfaces are the dominant mechanisms. However, it appears that other attenuation mechanisms are also very significant in site chemistry. A sequential extraction procedure developed to identify and quantify the structural components of aquifer sediments that bind chromium and other heavy metals indicated that the heavy metals here are tightly bound to the soil matrix (Asikainen and Nikolaidis, 1994). A summary of the sequential extraction analyses results of the soils in two locations is as follows. Significant spatial variability in extractable chromium was observed, and exchangeable fractions and organic bound fractions were found to

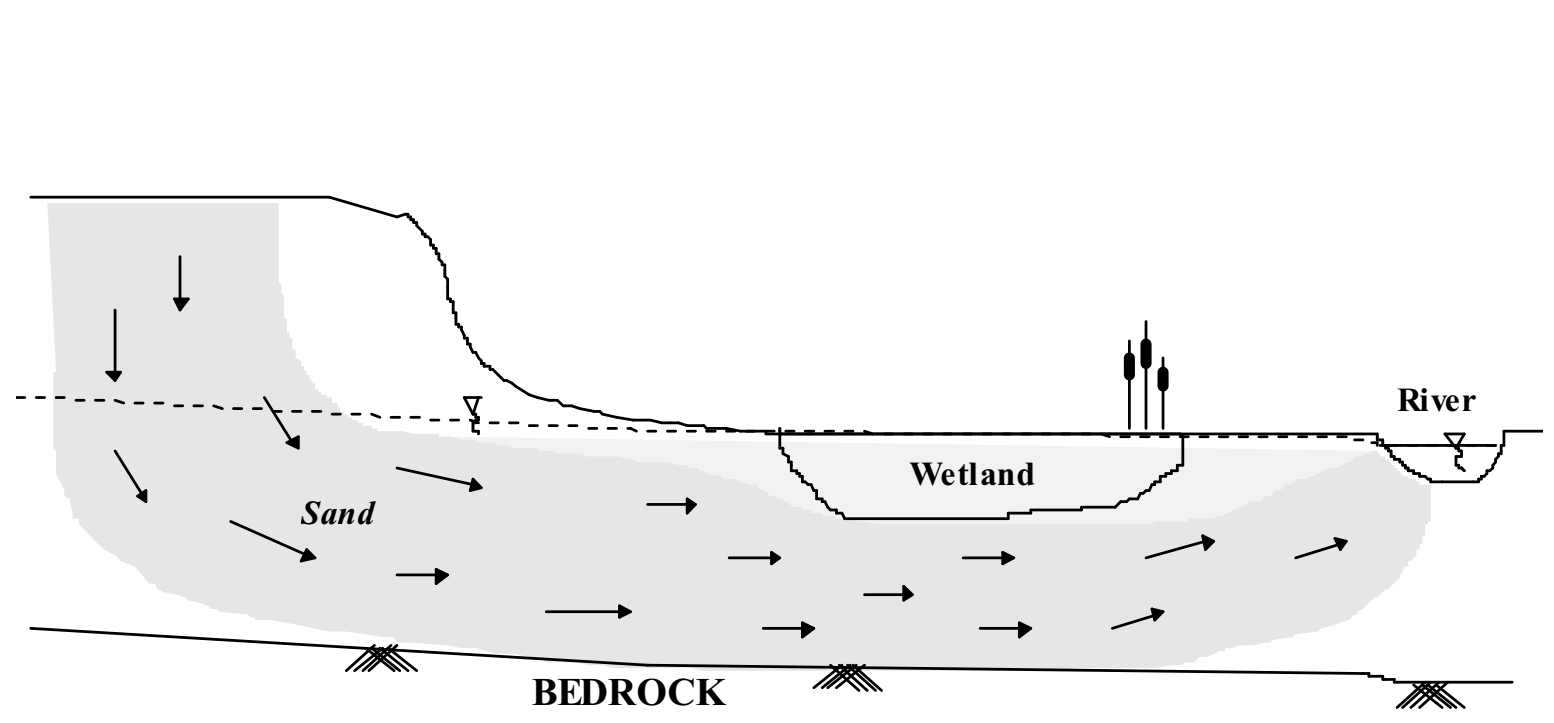

Figure 2. CSM for a ground water contaminated with heavy metals from a metal finishing facility. 
be statistically the same at the two locations. This was expected since the soil at the two locations is of the same geologic formation and contains similar amounts of organic matter. However, the oxide-bound and residual fractions are statistically different at the $95 \%$ confidence level. Higher concentrations of chromium were observed in soil samples obtained closer to the source of the contamination, compared to those obtained downgradient from the source. Nikolaidis and co-workers (1994) ascertained that the only difference that can explain the variability in accumulation in the oxide and residual fractions between the two locations is that the soils near the facility have been exposed for a longer time to the contaminants; thus they had a longer opportunity to diffuse into the particle matrix. The fact that a significant amount of chromium is tightly bound to the source suggests that a slow, kinetically-controlled attenuation mechanism is also influencing heavy metal mobility at the site. The strength of the extractants used in the Asikainen and Nikolaidis study (1994) indicates that only a fraction of the total chromium accumulation is readily exchangeable. These results were confirmed via sorption experiments on uncontaminated soil conducted by Scherer (1994) where it was shown that the maximum adsorption capacity of the soil for chromate at similar to ground water $\mathrm{pH}$ was statistically the same as the exchangeable and organic bound fraction of the sequential extraction analyses.

To confirm the slow, kinetically controlled processes, column leaching experiments were conducted at two different flow rates $(0.1 \mathrm{ml}$ $\min ^{-1}$ and $1 \mathrm{ml} \mathrm{min}^{-1}$ ) and two different ( $\mathrm{pH} 4$ and 7) influent $\mathrm{pH}$ values (Lackovic et al., 1997; Nikolaidis et al., 1999). Columns with high flow rates simulated the equivalent of 90 years of precipitation leaching. The results show that after simulating 90 years of precipitation, the rate of leaching of chromium was on the same order of magnitude as the rate of silica dissolution $\left(10^{-9}\right.$ to $10-13 \mathrm{~mol} \mathrm{~g}^{-1} \mathrm{~s}$ ) from glaciated soils due to acid rain. These results confirm the observations that slow processes control the rate of accumulation and the rate of leaching of chromium from contaminated soils. Comparing the mass fluxes leached from the $\mathrm{pH} 4$ columns and $\mathrm{pH} 7$ columns, one notices that the slow processes for most of the heavy metals are $\mathrm{pH}$-controlled.
These results have significant implications in defining the mobility of heavy metal contaminants in the subsurface. The rate of leaching of a particular contaminant depends on the strength of the binding of the heavy metal with the soil matrix, and these processes are shown to be slow.

These studies led us to the development of an augmented conceptual site model describing the fate, speciation, and transport of heavy metals in porous media (Shen and Nikolaidis, 1997; Nikolaidis et al., 1999). In this model, dissolved heavy metals interact with oxide coatings and soil organic matter found on the outer surfaces of soil grains (primary porosity) via surface complexation reactions. Both fractions have a limited capacity for binding heavy metals, primarily because their surface areas are small. For a fraction of the mass on the surface, these reactions have been shown to be relatively fast, when compared with ground water flow regimes typically found in glaciated environments, and it can be assumed that they are operating under equilibrium conditions. In addition, dissolved heavy metals diffuse into the matrix of the grains and react with intragranular sites. It appears that the capacity for binding heavy metals within the soil matrix is much larger than that for primary porosity. In addition, the rate of accumulation, as well as the rate of release of heavy metals from the soil matrix is very slow, and it controls the recovery time of heavy metal contaminated sites. This conceptual model was incorporated into the 1-D version of the Heavy Metal (HM1D) model and has been applied to unsaturated soils (Nikolaidis et al., 1999). In this work, the conceptual model is incorporated into the HM$3 \mathrm{D}$ version of the model and is used to simulate the behavior of chromium in ground water.

\section{HM-3D MODEL DESCRIPTION}

The objective of developing the HM model was to provide a model that is able to describe multicomponent solute transport, including aqueous complexation, surface complexation, precipitation-dissolution chemical reactions, and kinetic diffusive transport. Conceptually, the model was developed by modifying and merging a multicomponent chemical equilibrium model, MINEQL (Westall et al., 1976) with a saturated flow and transport model (McDonald and 
Table 1. Chemical Reactions of the HM-3D Model 1. aqueous complexation

$$
\begin{aligned}
& \mathrm{H}^{+}+\mathrm{CrO}_{4}^{-2}=\mathrm{HCrO}_{4}^{-} \\
& 2 \mathrm{H}^{+}+\mathrm{CrO}_{4}^{-2}=\mathrm{H}_{2} \mathrm{CrO}_{4} \\
& \mathrm{Cr}^{+3}+\mathrm{H}_{2} \mathrm{O}=\mathrm{CrOH}^{+2}+\mathrm{H}^{+} \\
& \mathrm{Cr}^{+3}+2 \mathrm{H}_{2} \mathrm{O}=\mathrm{Cr}(\mathrm{OH})_{2}^{+}+2 \mathrm{H}^{+}
\end{aligned}
$$

\section{2. surface complexation}

$$
\begin{aligned}
& \mathrm{FeOH}+\mathrm{H}^{+}+\mathrm{CrO}_{4}^{-2}=\left(\mathrm{FeOH}_{2}^{+} \cdot \mathrm{CrO}_{4}^{-}\right)^{-} \\
& \mathrm{FeOH}+2 \mathrm{H}^{+}+\mathrm{CrO}_{4}^{-2}=\mathrm{FeOH}_{2}^{+} \cdot \mathrm{HCrO}_{4}^{-} \\
& \mathrm{FeOH}+2 \mathrm{H}_{2} \mathrm{O}+\mathrm{Cr}^{+3}=\left(\mathrm{FeO}^{-} \cdot \mathrm{Cr}^{+3}\right)^{+}+2 \mathrm{H}^{+}
\end{aligned}
$$

\section{3. precipitation/dissolution}

$$
\mathrm{Cr}^{+3}+3 \mathrm{H}_{2} \mathrm{O}=\mathrm{Cr}(\mathrm{OH})_{3(\mathrm{~s})}+3 \mathrm{H}^{+}
$$

\section{4. redox}

$$
\begin{aligned}
& \mathrm{Cr}(\mathrm{VI})+3 \mathrm{Fe}(\mathrm{II})=\mathrm{Cr}(\mathrm{VI})+3 \mathrm{Fe}(\mathrm{III}) \\
& \mathrm{Cr}(\mathrm{VI})+\mathrm{Org}^{\mathrm{I}}=\mathrm{Cr}(\mathrm{III})+\mathrm{Org}^{\mathrm{II}}
\end{aligned}
$$

\section{5. diffusion into secondary pore of soil}

$$
\mathrm{Cr}_{\mathrm{aq}} \leftrightarrow \mathrm{Cr}_{2 \mathrm{nd}}
$$

Harbaugh, 1988) and adding kinetic diffusive transport and the kinetics of redox chemistry. The specific model components are described below:

\section{Saturated Groundwater Flow}

The flow of groundwater through the saturated soils is described by the three-dimensional fully saturated groundwater flow equation:

$$
\mathrm{S} \frac{\partial \mathrm{h}}{\partial \mathrm{t}}=\frac{\partial}{\partial \mathrm{x}} \mathrm{K}_{\mathrm{x}} \frac{\partial \mathrm{h}}{\partial \mathrm{x}}+\frac{\partial}{\partial \mathrm{y}} \mathrm{K}_{\mathrm{y}} \frac{\partial \mathrm{h}}{\partial \mathrm{y}}+\frac{\partial}{\partial \mathrm{z}} \mathrm{K}_{\mathrm{z}} \frac{\partial \mathrm{h}}{\partial \mathrm{z}}+\mathrm{q}(1)
$$

where $h$ is the hydraulic head (m); $S$ is the specific storage coefficient (dimensionless), $K_{x}\left(\mathrm{~m} \mathrm{~s}^{-1}\right), K_{y}$ $\left(\mathrm{m} \mathrm{s}^{-1}\right), K_{z}\left(\mathrm{~m} \mathrm{~s}^{-1}\right)$ are the hydraulic conductivity of the aquifer in the $x, y$, and $z$ directions respectively; $\mathrm{q}\left(\mathrm{m}^{3} \mathrm{~s}^{-1}\right)$ is the source term, and $t(\mathrm{~s})$ is the time.

\section{Multi-component Transport Equation}

The multi-component transport equation, written simplified in one-dimensional form, can be expressed as: $\mathrm{w} \frac{\partial T_{j}}{\partial t}+\frac{\partial}{\partial x}\left(u C_{j}-\mathrm{D} \frac{\partial C_{j}}{\partial x}\right)=Q_{j}$

where:

$T_{j}=$ Total concentration of component $\mathrm{j}$, (aqueous, adsorbed and precipitated concentrations)

$C_{j}=$ Sum of the aqueous species concentration of component $\mathrm{j}$

$Q_{j}=$ Source for component $\mathrm{j}$

$u=$ Darcy Flux

$w=$ porosity of aquifer

$D=$ Dispersion coefficient

\section{Multi-Component Chemical Model}

The multi-component chemical model describes chemical speciation, complexation, precipitation, and surface complexation reactions using the Triple Layer Model. The chemical reactions of the chromium system are shown in Table 1.

A batch equilibrium study was done on $\mathrm{Cr}$ (VI) adsorption using soil from the National Chromium Facility site (Scherer, 1994). The isotherm studies (taking 96 hours) were conducted with $\mathrm{pH}$ of about 5.0 and 5.7. To independently estimate the parameters of the TLM model, the isotherm data were used. The calibrated site concentration was $8.0 \times 10^{-6} \mathrm{~mol} \mathrm{~g}^{-1}$ soil. ICP analysis of the soil (Nikolaidis et al., 1994) indicated that the $\mathrm{Fe}$ content was about $5 \%$, which results in 16 $\mathrm{m}^{2} \mathrm{~g}^{-1} \mathrm{Fe}$. The concentrations of the simulated adsorbed $\mathrm{Cr}(\mathrm{VI})$ are plotted versus those of the observed for the best fit run in Figure $3 . \mathrm{R}^{2}$ was 0.91 .

Both homogeneous and heterogeneous reactions are incorporated into $\mathrm{Cr}(\mathrm{VI})$ reduction by soil organic matter through iron. It is assumed that organic matter reduces $\mathrm{Fe}$ (III) on the soil surface into $\mathrm{Fe}(\mathrm{II})$, which then dissolve and react with $\mathrm{Cr}(\mathrm{VI})$ in the solution, and that some $\mathrm{Cr}(\mathrm{VI})$ is adsorbed to $\mathrm{Fe}(\mathrm{II})$ on the soil surface and is reduced. The mechanism of Fe(III) reduction by Oxalate (Suter et al., 1991) was closely followed to develop the $\mathrm{Cr}(\mathrm{VI})$ reduction model in this study. The first step is dissolution of organic matter from the soil

$$
\operatorname{Org}_{\mathrm{s}} \rightarrow \text { Org }_{\mathrm{aq}}
$$

This is a reversible process, with forward and reversal reaction rate constants of $\mathrm{k}_{1 \mathrm{f}}$ and $\mathrm{k}_{1 \mathrm{r}}$. The second step is adsorption of aqueous organic matter on $\mathrm{Fe}(\mathrm{III})$ surface, 


$$
\mathrm{Org}_{\mathrm{aq}}+>\mathrm{Fe}^{\mathrm{III}} \rightarrow>\mathrm{Fe}^{\mathrm{III}} \mathrm{Org}
$$

This is again a reversible process. The third step is the reduction of the organic matter adsorbed on $\mathrm{Fe}(\mathrm{III})$ surface,

$$
>\mathrm{Fe}^{\mathrm{III}} \mathrm{Org} \rightarrow>\mathrm{Fe}^{\mathrm{II}}+\mathrm{Org}^{*}
$$

where Org* denotes reduced organic matter. Adsorption/desorption is fast compared to reduction of $\mathrm{Fe}$ (III) by organic, and therefore the two reactions can be combined into one:

$$
\mathrm{Org}_{\mathrm{aq}}+>\mathrm{Fe}^{\mathrm{III}} \rightarrow>\mathrm{Fe}^{\mathrm{II}}+\mathrm{Org}^{*}
$$

Its rate constant is $\mathrm{k}_{2}$. The next step is dissolution of FeII from the surface:

$$
>\mathrm{Fe}^{\mathrm{II}} \rightarrow \mathrm{Fe}^{\mathrm{II}} \text { aq }
$$

This reaction was also assumed to be reversible, and the forward and reversal constants are $\mathrm{k}_{3 \mathrm{f}}$ and $\mathrm{k}_{3 \mathrm{r}}$. Reduction of $\mathrm{Cr}(\mathrm{VI})$ by $\mathrm{Fe}(\mathrm{II})$ can occur on iron surfaces (Anderson et al., 1994),

$$
3>\mathrm{Fe}^{\mathrm{II}}+\mathrm{Cr}_{\text {aq }}^{\mathrm{VI}} \rightarrow \mathrm{Cr}^{\mathrm{III}}+3>\mathrm{Fe}^{\mathrm{III}}
$$

with rate constant of $\mathrm{k}_{4}$, as well as in the aqueous phase (Eary and Rai, 1989, 1991, Anderson et al., 1994),

$\mathrm{Cr}^{\mathrm{VI}}$ aq $+3 \mathrm{Fe}^{\mathrm{II}}{ }_{\text {aq }} \rightarrow \mathrm{Cr}^{\mathrm{III}}+3 \mathrm{Fe}^{\mathrm{III}}{ }_{\text {aq }}$

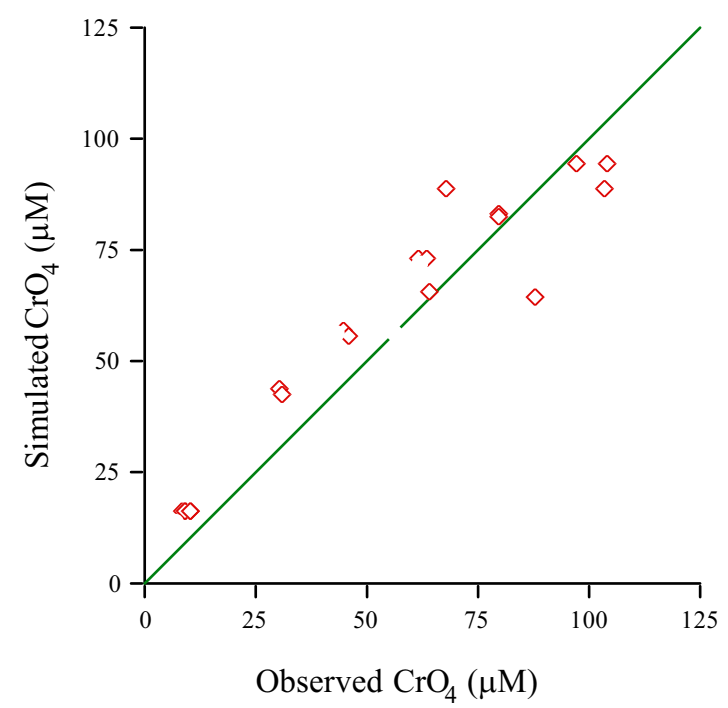

Figure 3. Adsorbed $\mathrm{CrO}_{4}$ : simulation versus observation. Diamonds denote data points at $\mathrm{pH}=5.0$, and circles denote data points at $\mathrm{pH}=5.7$. with rate constant of $\mathrm{k}_{5}$. Oxidation of $\mathrm{Cr}$ (III) by Mn-oxides is not incorporated in the model because XPS results show that Mn is not present in soil surfaces at the National Chromium site. The rate expressions for the system of chromium, iron, and organic matter are assumed as follows,

$$
\begin{aligned}
& \frac{\mathrm{d}}{\mathrm{dt}}\left[\mathrm{Org}_{\mathrm{s}}\right]=-\mathrm{k}_{1 \mathrm{f}}\left[\mathrm{Org}_{\mathrm{s}}\right]+\mathrm{k}_{1 \mathrm{r}}\left[\mathrm{Org}_{\mathrm{aq}}\right] \\
& \frac{\mathrm{d}}{\mathrm{dt}}\left[\mathrm{Org}_{\mathrm{aq}}\right]=-\mathrm{k}_{1 \mathrm{f}}\left[\mathrm{Org}_{\mathrm{s}}\right]-\mathrm{k}_{1 \mathrm{r}}\left[\mathrm{Org}_{\mathrm{aq}}\right]- \\
& -\mathrm{k}_{2}\left[\mathrm{Org}_{\mathrm{aq}}\right]\left\{>\mathrm{Fe}^{\mathrm{III}}\right\} \\
& \frac{\mathrm{d}}{\mathrm{dt}}\left\{>\mathrm{Fe}^{\mathrm{II}}\right\}=\mathrm{k}_{2}\left[\mathrm{Org}_{\mathrm{aq}}\right]\left\{>\mathrm{Fe}^{\mathrm{III}}\right\}- \\
& -\mathrm{k}_{3 \mathrm{f}}\left\{>\mathrm{Fe}^{\mathrm{II}}\right\}+\mathrm{k}_{3 \mathrm{r}}\left[\mathrm{Fe}^{\mathrm{II}}{ }_{\mathrm{aq}}\right]- \\
& -3 \mathrm{k}_{4}\left\{>\mathrm{Fe}^{\mathrm{II}}\right\}\left[\mathrm{Cr}^{\mathrm{VI}}{ }_{\text {aq }}\right] \\
& \frac{\mathrm{d}}{\mathrm{dt}}\left[\mathrm{Fe}^{\mathrm{II}}\right]=\mathrm{k}_{3 \mathrm{f}}\left\{>\mathrm{Fe}^{\mathrm{II}}\right\}- \\
& -\mathrm{k}_{3 \mathrm{r}}\left[>\mathrm{Fe}^{\mathrm{II}}{ }_{\text {aq }}\right]-3 \mathrm{k}_{5}\left[\mathrm{Cr}^{\mathrm{VI}}{ }_{\text {aq }}\right]\left[\mathrm{Fe}^{\mathrm{II}}{ }_{\text {aq }}\right] \\
& \frac{\mathrm{d}}{\mathrm{dt}}\left[\mathrm{Cr}^{\mathrm{VI}}\right]=-\mathrm{k}_{4}\left\{>\mathrm{Fe}^{\mathrm{II}}\right\}\left[\mathrm{Cr}^{\mathrm{VI}}{ }_{\text {aq }}\right]- \\
& -\mathrm{k}_{5}\left[\mathrm{Cr}^{\mathrm{VI}}{ }_{\mathrm{aq}}\right]\left[\mathrm{Fe}^{\mathrm{II}}{ }_{\text {aq }}\right]
\end{aligned}
$$

where k's are rate constants, $>$ denotes surface sites, and subscript aq denotes aqueous phase. The rate constants are a function of $\mathrm{pH}$ in the solution. Eary and Rai (1989) found that Cr(VI) reduction by ferrous ions derived from hematite was limited by ferrous ion dissolution from the solid phase, and that the apparent reduction rate constant was proportional to $\left[\mathrm{H}^{+}\right]^{\mathrm{n}}$, where $\mathrm{n}$ equals $0.76 \pm 0.05$. Hence $\mathrm{k}_{3 \mathrm{f}}$ in this model can be approximated as

$$
\mathrm{k}_{3 \mathrm{f}}=\mathrm{k}_{30}\left[\mathrm{H}^{+}\right]^{0.76}
$$

Suter et al. (1991) suggest that the reduction of adsorbed oxalate was slow compared to ferrous ion dissolution. Similarly, reaction of equation (3.1) is slower than that of equation (3.2). Eary and Rai (1991) find that the rate of reduction of $\mathrm{Cr}(\mathrm{VI})$ by soil increases with decreasing $\mathrm{pH}$. One can assume that

$$
\mathrm{k}_{2}=\mathrm{k}_{20}\left[\mathrm{H}^{+}\right]^{\mathrm{m}}
$$

where $\mathrm{k}_{20}$ and $\mathrm{m}$ are two parameters to be determined. 
The flux of chromium between the bulk of the solution and the soil matrix was assumed to be of first order:

$$
\text { flux }=\mathrm{k}_{\text {diff }} \mathrm{a}\left(\mathrm{C}_{\mathrm{aqu}}-\mathrm{C}_{2 \text { nd }}\right)
$$

where $\mathrm{C}_{2 \text { nd }}$ is the aqueous chromium concentration in the matrix, $\mathrm{C}_{\mathrm{aqu}}$ is the aqueous chromium concentration, $\mathrm{k}_{\mathrm{diff}}$ is the mass transfer coefficient, and a is an effective cross-section area between the pores of the aquifer and cracks inside the soil grain. Assuming that chromium concentration at the surface and in solution inside the soil matrix was linear, then

$$
\mathrm{q}_{2 \mathrm{nd}}=\mathrm{k}_{2 \mathrm{nd}} \mathrm{C}_{2 \mathrm{nd}}
$$

where $k_{2 n d}$ is another parameter. $k_{2 n d}$ and $\left(k_{\text {diff }} \mathrm{a}\right)$ will be obtained through the calibration process in the field. $\mathrm{V}_{2 \text { nd }}$ denotes the volume of water in the soil matrix per unit mass of soil. The total mass of chromium in the soil matrix per unit mass of soil is

$$
\mathrm{Q}_{2 \text { nd }}=\mathrm{q}_{2 \text { nd }}+\mathrm{C}_{2 \text { nd }} \mathrm{V}_{2 \text { nd }}
$$

Since $\mathrm{C}_{2 \text { nd }}$ is comparable to $\mathrm{C}_{\mathrm{aqu}}$, and $\mathrm{V}_{2 \text { nd }}$ is much smaller than the volume of the primary pores, the term $\mathrm{C}_{2 n d} \mathrm{~V}_{2 \text { nd }}$ is safely neglected in the system. That is, the total chromium mass in the soil matrix is $\mathrm{q}_{2 \mathrm{nd}}$.

\section{MODEL APPLICATION}

The depth-to-bedrock of the simulated aquifer is 29 to 45 feet thick. The simulation region was spatially divided into 20x30 uniform cells. The cell dimensions were 5 by 5 meters. The coordinate directions were aligned with the groundwater flow direction. The aquifer was vertically divided into five layers with thickness of about 2 meters. The cell thickness varied spatially, and the top layer thickness varied over time due to the fluctuation of groundwater.

Twenty-one observation wells were installed on the site, 12 of which were inside or at the boundary of the region of interest. Well water elevations from Dec. 20, 1991 to Dec. 30, 1992 were used to calibrate the model parameters. Although the hydraulic heads of all the boundary cells are needed for simulation, only six wells were located at the boundary of the simulation region. The heads of the remaining boundary cells were estimated from the well water elevations using interpolation and extrapolation. Three types of aquifer material are present at the site: till, gravel to coarse sand, and fine to coarse sand. Slug tests indicated that the hydraulic conductivity of the aquifer ranges from 0.0001 to $0.0048 \mathrm{~cm}$ $\mathrm{s}^{-1}$ (Nikolaidis et al., 1994). The three different aquifer materials were assigned different hydraulic conductivity values during calibration.

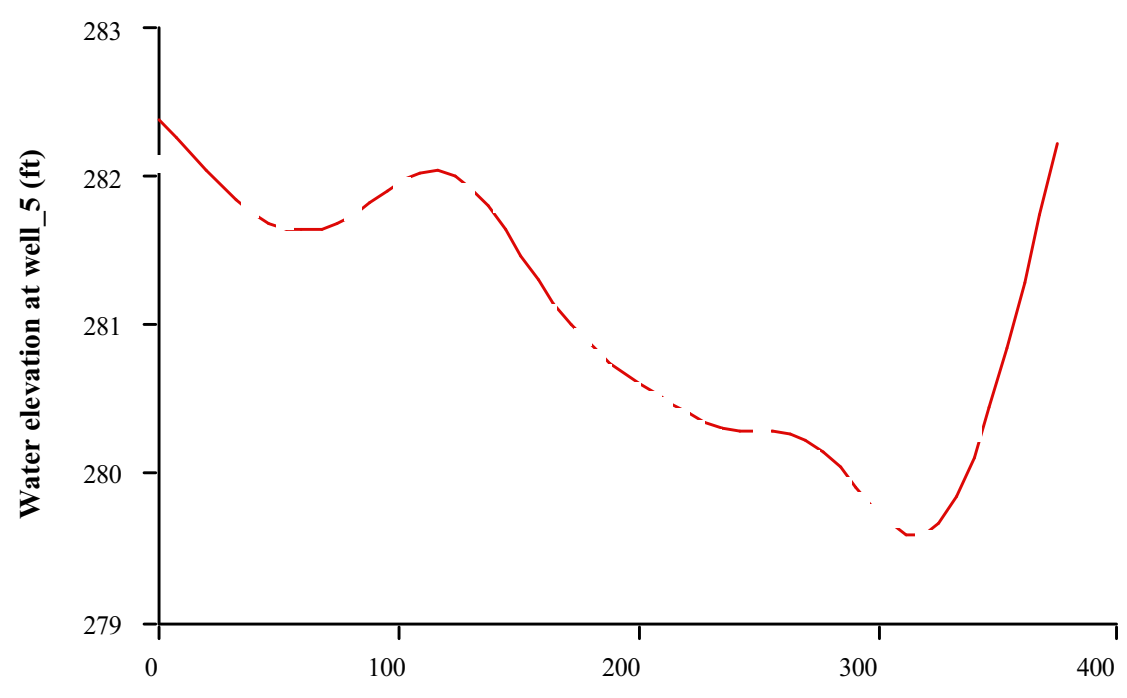

Time (days)

Figure 4. Water elevations at well 5. Squares denote observations, and the dashed line represents the fitted data. 
Using the one-year long weekly water level measurements, the model was used to simulate the water levels in the domain of the site. The results for one of the well located down gradient from the source of contamination are shown in Figure 4. The fraction of variance predicted by the simulation, represented by $\mathrm{R}^{2}$, varied from 0.75 to 0.92 , with one exception at well 12 . Even though $\mathrm{R}^{2}$ for well 12 was only 0.30 , the simulation fitted the last 9 months of data well.

The calibrated hydrologic model was used to generate the water levels between 1939 and 1992. This information was necessary for the simulation of the fate and transport of chromium at the site. The time series data for the simulation period were generated using the one-year weekly water level measurements collected at the site. The data were fitted with a 10 term sinusoidal function series and a constant term,

$\mathrm{H}_{\text {fit }}(\mathrm{t})=\mathrm{b}_{0}+\sum_{\mathrm{i}=1}^{10} \mathrm{~b}_{\mathrm{i}} \sin \left(\frac{\mathrm{p}}{365.25} \frac{\mathrm{i}}{10} \mathrm{t}\right)$

where $\mathrm{H}_{\text {fit }}$ is the fitted well water elevations and $\mathrm{b}_{0}$ and $b_{i}$ are fitting parameters. The end of time series is $\mathrm{t}=0$. The generated time series for each cell were placed back to back to create a 50-year time series for each boundary well. These boundary cell heads were used to drive the hydrologic model and generate the flow regime for the 50year long simulation of chromium.

The HM-3D model was calibrated by adjusting the following parameters: a) longitudinal and transverse dispersivity, $b$ ) the source strength of chromium, c) the source strength of acidity, d) adsorption site concentration, e) reducing rate constant and capacity of the soil, and f) diffusion rate constant and capacity of the soil. The parameter was adjusted in such a way that the simulated aqueous and solid phase chromium concentrations were similar to the observed data measured at the site. In particular, the aqueous and soil chromium concentrations at the end of the 50-year simulation were compared with those obtained from the multilevel nests ML1 and ML2 (Nikolaidis et al., 1994). The calibrated parameter values are shown in Table 2.

Figure 5 presents the model calibration results at the end of the 50-year long simulation, for a cell down-gradient from the source of contamination, in the middle of the chromium plume. At that location, multi-level well, ML2 having 8 vertical probes was installed and aqueous and soil chromi-
Table 2. Values of Calibrated Parameters of the HM3D Model

\begin{tabular}{|lr|}
\hline Longitude dispersivity $(\mathrm{m})$ & 0.5 \\
Transverse dispersivity $(\mathrm{m})$ & 0.1 \\
Source strength of chromium ${ }^{1}$ & $25 \%$ \\
Source strength of acidity ${ }^{2}$ & 1.1 \\
Adsorption capacity $\left(\mathrm{g}-\mathrm{Cr} \mathrm{g}^{-1}\right.$-soil) & 0.083 \\
Reducing rate constant $\left(\mathrm{sec}^{-1}\right)$ & 5.0 \\
Reducing capacity $\left(\mathrm{g}^{-} \mathrm{Cr} \mathrm{g}^{-1}\right.$-soil) & 0.021 \\
Diffusion rate constant $\left(\mathrm{sec}^{-1}\right)$ & $10^{-6}$ \\
Diffusion capacity $\left(\mathrm{g}^{-} \mathrm{Cr} \mathrm{g}^{-1}\right.$-soil) & $0.078-0.19$
\end{tabular}

${ }^{1}$ the portion of total purchased chromium

2 mole ratio of acid to chromium

um concentrations have been measured (Nikolaidis et al., 1994). In addition, sequential extraction analyses were conducted on the soil that differentiate between the diffused and adsorbed fractions of chromium on the soil (Asikainen and Nikolaidis, 1994). Figure 5 compares the model simulation diffused, adsorbed and aqueous chromium concentrations with the measured data. The measured data are presented as a mean and a standard deviation. The results indicated that the simulated diffused chromium concentrations were within the standard deviation of the observed data at ML2. The simulated adsorbed concentrations were also in good agreement with the measured data. The simulated aqueous chromium concentrations for the 3 lower layers were in good agreement with the observed data and the two upper layers over-predicted the observed variability. In general, the HM-3D model was capable to describe the geochemistry of the chromium plume at the site.

Once a model is calibrated, it can then be used to evaluate pump-and-treat remedial alternatives. Several pump-and-treat scenarios were evaluated. The scenarios consisted of a single fully penetrating groundwater extraction well, pumping between 10 gpm, $15 \mathrm{gpm}$ and $20 \mathrm{gpm}$, for a ten year time period. The results of these simulations are shown on Figure 6 . These pumping scenarios yielded chromium removal amounts of 1,300 to $2,300 \mathrm{~kg}$ of chromium over a 10-year pumping period. Most of the aqueous chromium was removed, as the average aqueous concentration of chromium at the pumping well continued to decline. The majority of 

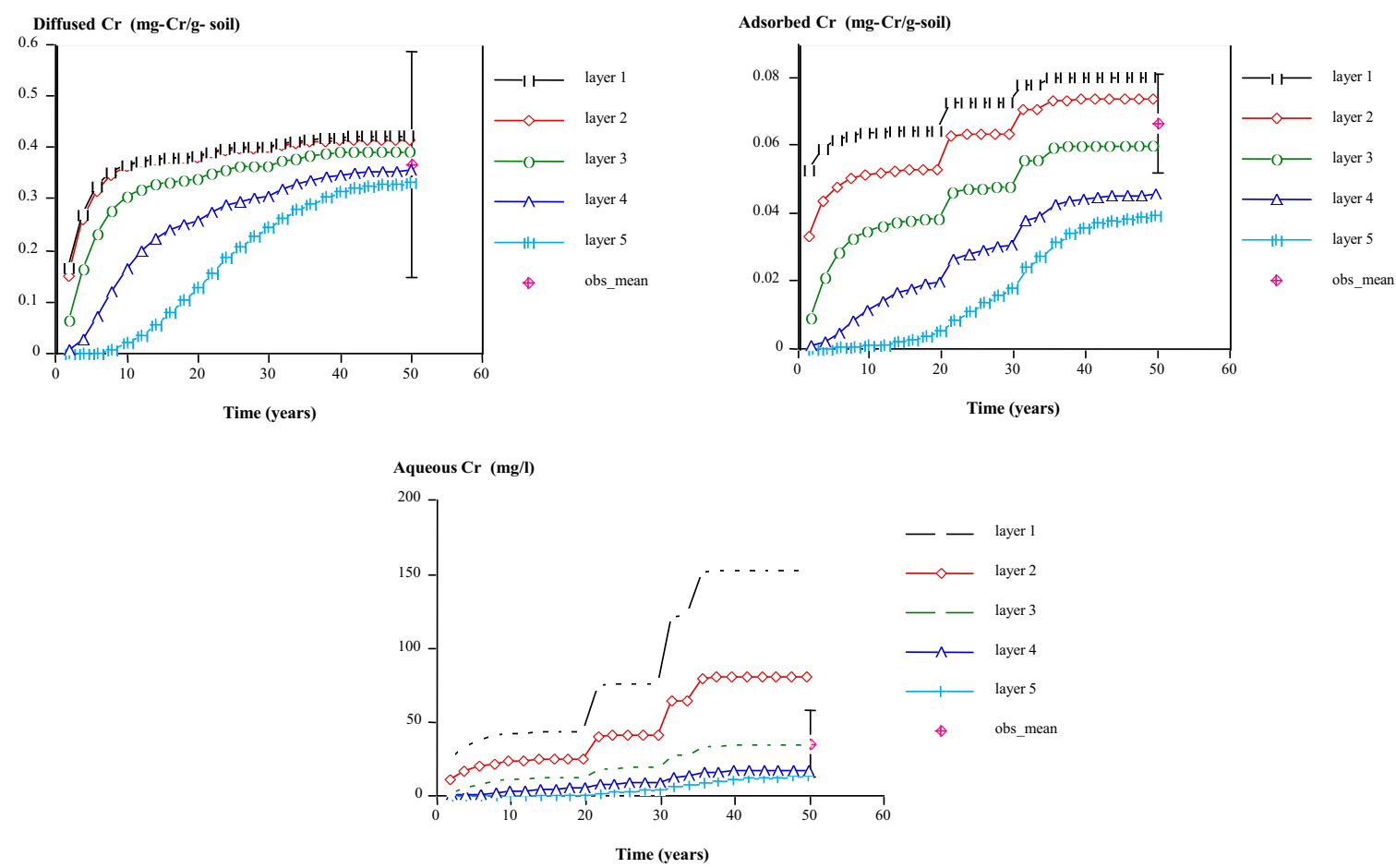

Figure 5. Model Calibration Results - Comparison of simulated chromium concentrations with observed data.

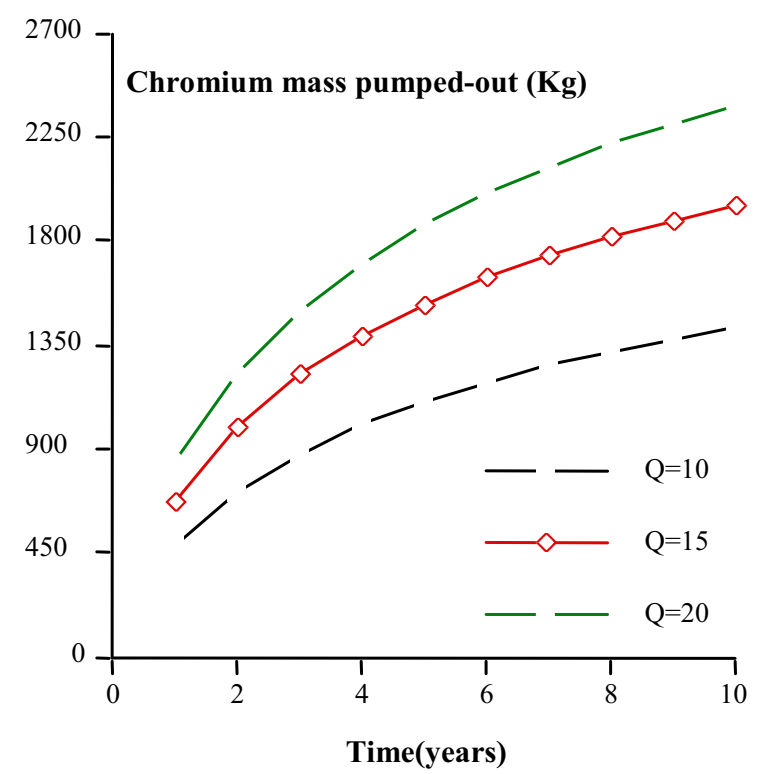

Figure 6. Pump-and-Treat Remediation Scenarios Mass of Chromium pump-out at 3 pumping rates of 10,15 and $20 \mathrm{gpm}$

the remaining chromium was diffused into the soil matrix. In December of 1995, National Chromium Inc. installed and initiated operation of a fully penetrated extraction well in the vicinity of ML2. An evaluation of the pumping data for a two-year period revealed that the average pumping rate was 20.2 gpm and the total mass of chromium removed from the subsurface was $1,307 \mathrm{~kg}$. The HM-3D simulation of $20 \mathrm{gpm}$ indicated that the total mass of chromium to be removed was $1,222 \mathrm{~kg}$. The model predicted the extracted mass of chromium within a $6.5 \%$ error. These results confirm the validity and utility of the CSM model.

Conceptual site models can be used as effective planning tools that guide site investigations through an assessment framework that integrates new site information as it becomes available. Incorporation of an augmented CSM into a transport model can be used to assess the mobility of contaminants and evaluate remedial alternatives. The hydrology and geochemistry of the National Chromium groundwater was modeled accurately using the HM-3D model. The model was capable to predict the amount of chromium that was pumped-out of the aquifer during a two-year pump-and-treat remediation period. The success of the model is due to the augmented CSM developed for the site that accurately depicted the predominant processes that control the fate and transport of chromium in the ground water. 


\section{REFERENCES}

Anderson, L. D., Kent, A.B. and Davis, J.A. (1994), Batch experiments characterizing the reduction of Cr(VI) using suboxic material from a mildly reducing sand and gravel aquifer, Environmental Science and Technology, 28, 178-185.

Asikainen, J.M. and Nikolaidis, N.P. (1994), Sequential extraction of chromium from contaminated aquifer sediments, Groundwater Monitoring and Remediation, 14, 185-191.

Bear J. and Verruijt, A. (1987), Theory and applications of transport in porous media, Reidel Publishing Company, Dordrecht, Holland.

Eary, L.E. and Rai, D. (1989), Kinetics of chromate reduction by ferrous ions derived from hematite and biotite at $25^{\circ} \mathrm{C}$, American Journal of Science, 289, 180-213.

Eary, L.E. and Rai, D. (1991), Chromate reduction by subsurface soil under acidic conditions, Soil Science Soc. of Am. J. 55, 676-683.

Lackovic, J., Nikolaidis, N.P., Chheda, P. and Carley, R. (1996), An evaluation of batch leaching procedure for heavy metal mobility estimates from soils, Technical Report ERI-96.04, Environmental Research Institute, University of Connecticut, Storrs, CT.

Lackovic, J.A., Nikolaidis, N.P., Cheeda, P., Carley, R.J. and Patton, E. (1997), Evaluation of batch leaching procedures for estimating heavy metal mobility in glaciated soils, Groundwater Monitoring and Remediation, 17, 231-240.

Marsily, G. de (1986), Quantitative Hydrology: Groundwater Hydrology for Engineers, Academic Press, New York.

Mattuck, R. and Nikolaidis, N.P. (1996), Chromium mobility in freshwater wetlands, Journal of Contaminant Hydrology, 23, 213-232.

McDonald, M. G. and Harbaugh, (1988), A modular three-dimensional finite difference groundwater flow model, USGS TWRI.

Nielsen, D.M. (1991), Practical handbook of ground-water monitoring, Lewis, Chelsea, MI.

Nikolaidis, N.P., Hellerich, L.A. and Lackovic, J.A. (1999), Methodology for Site-Specific, Mobility-Based Cleanup Standards for Heavy Metals in Glaciated Soils, Environmental Science and Technology, 33, 2910-2916.

Nikolaidis, N.P., Robbins, G.A., Scherer, M., McAninch, B., Binkhorst, G., Asikainen, J.M. and Suib, S. (1994), Vertical distribution and partitioning of chromium contamination in a glacio-fluvial aquifer, Groundwater Monitor and Remediation, 14, 150-159.

Olazabal, M.A., Nikolaidis, N.P., Suib, S.L. and Madariaga, J.M. (1997), Precipitation equilibria of the $\mathrm{Cr}(\mathrm{VI}) / \mathrm{Fe}(\mathrm{III})$ system and spectrospcopic characterization of the precipitates, Environmental Science and Technology, 31, 2898 - 2902.

Scherer, M.M. (1994), Equilibrium studies of chromate adsorption on glacio-fluvial aquifer sediments, M.S., Environmental Engineering Program, Univ. of Connecticut, Storrs, CT.

Shen, H. (1996), Modeling of multicomponent transport in groundwater and its application to chromium system, Ph.D. Dissertation, Environmental Engineering Program, University of Connecticut, Storrs, CT.

Shen, H. and Nikolaidis N.P. (1997), A direct substitution method for multicomponent solute transport in ground water, Ground Water, 35, 67-78.

Suter, D., Banwart, S. and Stumm, W. (1991), Dissolution of hydrous iron (III) oxides by reductive mechanisms, Langmuir, 7, 809-813.

Westall, J., Zachary, C.L. and Morel, F.M.M. (1976), MINEQL, A computer program for the calculation of chemical equilibrium composition of aqueous system, Dept. of Civ. Eng., MIT, MA. Tech. Note 18. 